\title{
ANALISIS DAYA SAING USAHATANI KOPI ROBUSTA (COFFEA CANEPHORA) DI KABUPATEN REJANG LEBONG
}

\author{
The Competitiveness of Robusta Coffee Farming in Rejang Lebong \\ District
}

\author{
Fery Murtiningrum, Putri Suci Asriani, dan Redy Badrudin \\ Program Pascasarjana Magister Agribisnis, Fakultas Pertanian \\ Universitas Bengkulu
}

\begin{abstract}
The research objectives are to 1) analyse the competitive advantage of robusta coffee farm in Rejang Lebong Regency, 2) analyse the comparative advantage of robusta coffee farm in Rejang Lebong Regency, 3) analyse the impact of government policy toward competitive robusta coffee in Rejang Lebong Regency, 4) analyse the sensitivity of competitive of robusta coffee toward the changing of input-output. The areas of the research are selected by purposive method. It considered that Rejang Lebong is one of regency in Bengkulu that is have been planted robusta coffee from one generation to others and makes coffee become superior commodity. Selecting sample is done by using stratified random sampling method. The sample is 32 respondents. The result analysis is using Policy Analysis Matrix (PAM). The research result shows that robusta coffee in Rejang Lebong has high competition (competitive advantage and comparative advantage). It is known that DRCR value is smaller than one, about 0,37 and 0,23. The impact of government policy toward input of the result analysis using PAM method is IT value is negative Rp.1.197.108/ha/year. Input Transfer (IT) value describes the policy (subsidy or tax) happened in tradable input production. IT value is negative for robusta coffee farm. It indicates that there is a policy subsidy toward tradable (anorganic fertilizer) input production in coffee farm. That is an advantage for coffee farmer. For output, IT value factor is positive 10.296. It indicates that there is a government policy toward domestic input such as tax. The input-output policy doesn't work effectively or support or protect the coffee farmer in Rejang Lebong. The government policy is applied in coffee trade, so it causes coffee farmer doesn't accept the price of coffee as social price. The sensitivity analysis result shows that robusta coffee farm has good competitive (competitive advantages and comparative). The factor assumption is constant with PCR and DRCR value less than one. Combination sensitivity analysis shows that input and output changing is caused by the decreasing of robusta coffee farmer competitive in Rejang Lebong. It is shown in competitive advantage with the PCR value more than one, about 2,43 and comparative advantage with DRCR value smaller than one, about 0,44.
\end{abstract}

Keywords: Robusta Coffee, PAM, Competitive, Comparative 


\section{PENDAHULUAN}

Bagi bangsa Indonesia kopi merupakan salah satu komoditas unggulan dan penting. Pada tahun 1981 dihasilkan devisa sebesar US\$347,8 Juta dari ekspor kopi sebesar 210.800 ton. Nilai ini terus meningkat dari tahun ke tahun dan bagi Provinsi Bengkulu, kopi merupakan salah satu tanaman perkebunan yang memberikan peranan terbesar dalam pembentukan Produk Domestik Bruto, dan setiap tahun terus mengalami peningkatan produksi (BPS, 2011).

Salah satu Kabupaten yang menjadikan kopi sebagai komuditas unggulan yang memberikan kontribusi PDRB yang cukup besar adalah Kabupaten Rejang Lebong. Untuk Kabupaten Rejang Lebong pada kurun waktu 2005 -2011 perkembangan luas dan produksi tanaman perkebunan menunjukkan kencenderungan peningkatan baik jenis maupun produksinya. Dari data luas lahan dan produksi kopi yang menunjukkan perkembangan yang signifikan ini, maka kemudian perlu diketahui bagaimana dengan kesiapan daya saing ataupun keungggulan kompetitif, komparatif yang dimiliki oleh komoditi kopi yang di hasilkan oleh Kabupaten Rejang Lebong ini dan dampak kebijakan pemerintah dalam penerapan harga dan mekanisme pasar. Hal inilah yang kemudian menjadi dasar peneliti untuk melakukan suatu penelitian yang terkait dengan daya saing komoditi Kopi di Kabupaten Rejang Lebong.

\section{METODE PENELITIAN}

Penentuan lokasi penelitian di lakukan dengan sengaja di Desa Air Bening Kecamatan Bermani Ulu Raya dengan dasar pertimbangan desa ini merupakan daerah yang memproduksi $90 \%$ dari total produksi Kabupaten Rejang Lebong (Panggabean, 2011). Jumlah sampel yang diambil dari 318 petani responden yang melakukan kegiatan usahatani kopi yang terbagi menjadi populasi Tanaman Belum Menghasilkan (TBM) 127 petani, 109 petani Tanaman Menghasilkan (TM), dan 82 petani Tanaman Tidak Menghasilkan (TTM), dan diambil secara simple random sampling sebanyak $10 \%$ dengan pertimbangan jumlah ini sudah memenuhi kebutuhan untuk penelitian. Maka jumlah sampel yang diambil 13 orang sampel dari populasi TBM, 11 petani TM, dan 8 petani TTM. Jumlah keseluruhan sampel adalah 32 petani. Sedangkan untuk informan kunci seperti pedagang pengumpul di tingkat desa dan kecamatan, Pedagang Besar pada tingkat kabupaten, dan pedagang pengecer ditentukan secara sengaja (purposive) dengan maksud untuk mempermudah perolehan informasi yang lebih mendalam dan terarah.

Data yang dibutuhkan dalam penelitian ini adalah data primer dan data sekunder. Data primer diperoleh dari wawancara kepada sejumlah petani, informan dan pengusaha yang terlibat langsung dalam kegiatan usahatani kopi

2 | Fery Murtiningrum, Putri Suci Asriani, dan Redy Badrudin, Analisis Daya. 
dan pengembangan komoditas kopi. Data sekunder dikumpulkan dari berbagai literature, dokument hasil penelitian pada instansi pertanian, perkebunan, BPS, dan instansi terkait lainnya.

Data dikumpulkan melalui wawancara mendalam (in-dept interview), kelompok diskusi terarah (FGD), serta observasi lapangan pada lokasi pengembangan komoditas kopi. Pengambilan data kepada responden pada saat wawancara di lakukan dengan menggunakan daftar pertanyaan (quetionary), sementara informan dilakukan melalui kelompok diskusi terarah (FGD). Penelitian ini akan menggunakan metode PAM (Policy Analysis Matrix). Model PAM dengan formulasi seperti pada Tabel 1.

Tabel 1. Policy Analysis Matrix (PAM)

\begin{tabular}{lcccc}
\hline \multirow{2}{*}{ Uraian } & \multirow{2}{*}{ Penerimaan } & \multicolumn{2}{c}{ Biaya Input } & \multirow{2}{*}{ Keuntungan } \\
\cline { 3 - 4 } & & Tradable & Non tradable & \\
\hline Harga Pasar & $\mathrm{A}$ & $\mathrm{B}$ & $\mathrm{C}$ & $\mathrm{D}=\mathrm{A}-\mathrm{B}-\mathrm{C}$ \\
Harga Sosial & $\mathrm{E}$ & $\mathrm{F}$ & $\mathrm{G}$ & $\mathrm{H}=\mathrm{E}-\mathrm{F}-\mathrm{G}$ \\
Divergensi & $\mathrm{I}=\mathrm{A}-\mathrm{E}$ & $\mathrm{J}=\mathrm{B}-\mathrm{F}$ & $\mathrm{K}=\mathrm{C}-\mathrm{G}$ & $\mathrm{L}=\mathrm{I}-\mathrm{J}-\mathrm{K}$ \\
\hline
\end{tabular}

Sumber: Monke and Pearson (1989)

Keterangan:

Penerimaan usahatani kopi pada harga privat $=\mathrm{A}$

Total biaya tradable usahatani kopi pada harga privat $=\mathrm{B}$

Total biaya nontradable usahatani kopi pada harga privat $=\mathrm{C}$

Tingkat keuntungan pada harga privat $=\mathrm{D}$

Penerimaan usahatani kopi pada harga sosial $=\mathrm{E}$

Total biaya tradable usahatani kopi pada harga sosial $=\mathrm{F}$

Total biaya non tradable usahatani kopi pada harga sosial = G

Keuntungan sosial $=\mathrm{H}$

Transfer output $(\mathrm{OT})=\mathrm{I}$

Transfer input (IT) $=\mathrm{J}$

Transfer factor $(\mathrm{TF})=\mathrm{K}$

Transfer bersih $(\mathrm{NT})=\mathrm{L}$

Baris pertama pada Matrik PAM di Tabel 1 merupakan perhitungan yang menggunakan harga pasar (privat), yaitu harga yang betul-betul dibayarkan atau diterima petani. Baris kedua pada Tabel 1 adalah penghitungan yang didasarkan pada harga sosial (shadow price), yaitu harga yang menggambarkan nilai sosial yang sesungguhnya bagi unsur biaya maupun hasil. Selisih antara perhitungan yang didasarkan harga privat dengan harga sosial mengindikasikan dampak kebijaksanaan yang diterima oleh petani kopi. 
ISSN: 1412-8837

Tabel 2. Uraian indikator PAM

\begin{tabular}{cll}
\hline Uraian & Indikator & Hasil \\
\hline Keunggulan Kompetitif: & & \\
a. Private Provitability & $\mathrm{D}$ & $\mathrm{D}>0$, sistem komoditas tersebut \\
& & memperoleh profit diatas normal yang \\
& mempunyai implikasi bahwa komoditas itu \\
& mampu ekspansi. \\
& $\mathrm{D} \leq 0$, sistem komoditas tersebut \\
& memperoleh profit dibawah normal yang \\
& artinya bahwa komoditas itu belum mampu \\
& ekspansi. \\
\hline
\end{tabular}

b. Private cost ratio $\quad \mathrm{PCR}=\quad \mathrm{PCR}<1$, sistem komoditas yang diteliti

$\mathrm{C} /(\mathrm{A}-\mathrm{B}) \quad$ memiliki keunggulan kompetitif.

$\mathrm{PCR} \geq 1$, sistem komoditas yang diteliti tidak memiliki keunggulan kompetitif.

Keunggulan Komparatif:

a. Sosial Provitability
$\mathrm{H}$
$\mathrm{H}>0$, berarti ada efisiensi dari sistem komoditas pada kondisi tidak ada divergensi dan penerapan kebijaksanaan efisien.

$\mathrm{H} \leq 0$, berarti sistem komoditas tidak mampu bersaing tanpa bantuan dan intervensi pemerintah.

DRCR $<1$, sisem komoditas mempunyai

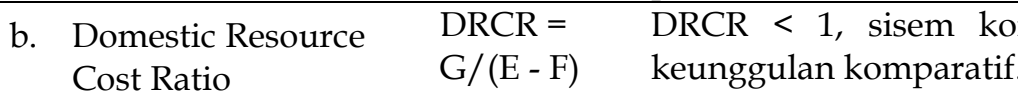

DRCR $\geq 1$, sistem komoditas tidak mempunyai keunggulan komparatif.

Dampak Kebijakan

Kebijakan output

a. Output Trasfer $\quad$ OT $=\mathrm{A}-\mathrm{E} \quad \mathrm{OT}>0$, menunjukkan adanya transfer dari masyarakat (konsumen) ke produsen.

OT $\leq 0$, menunjukkan tidak adanya transfer dari masyarakat (konsumen) ke produsen.

$\begin{array}{lll}\text { b. Nominal Protection } & \mathrm{NPCO}= & \mathrm{NPCO}>1, \text { Kebijakan bersifat proteksi } \\ \text { Coefficient on } & \mathrm{A} / \mathrm{E} & \text { terhadap output dan semakin besar nilai } \\ \text { Output } & & \text { NPCO semakin tinggi tingkat proteksi } \\ & & \text { pemerintah terhadap output. } \\ & \\ & \end{array}$

Kebijakan Input

a. Input Trasfer IT = B - F IT $>0$, menunjukkan adanya transfer dari petani ke produsen input tradable.

IT $\leq 0$, menunjukkan tidak adanya transfer dari petani ke produsen input tradable.

4 | Fery Murtiningrum, Putri Suci Asriani, dan Redy Badrudin, Analisis Daya. 


\begin{tabular}{|c|c|c|}
\hline Uraian & Indikator & Hasil \\
\hline $\begin{array}{l}\text { b. Nominal Protection } \\
\text { Coeffisien on } \\
\text { Tradable Input }\end{array}$ & $\begin{array}{l}\mathrm{NPCI} \\
\mathrm{B} / \mathrm{F}\end{array}$ & $\begin{array}{l}\text { NPCI }<1 \text {, berarti kebijakan bersifat protektif } \\
\text { terhadap input, ada kebijakan subsidi } \\
\text { terhadap input tradable. } \\
\text { NPCI } \geq 1 \text {, berarti tidak ada kebijakan } \\
\text { protektif terhadap input/tidak ada kebijakan } \\
\text { subsidi terhadap input tradable. }\end{array}$ \\
\hline c. Transfer Factor & $\mathrm{TF}=\mathrm{C}-\mathrm{G}$ & $\begin{array}{l}\mathrm{TF}>0 \text {, berarti ada transfer dari petani } \\
\text { produsen kepada produsen input tradable. } \\
\mathrm{TF} \leq 0 \text {, berarti tidak ada transfer dari petani } \\
\text { produsen kepada produsen input tradable. }\end{array}$ \\
\hline Kebijakan Input Output & & \\
\hline $\begin{array}{l}\text { a. Efective Protection } \\
\text { Coefficient }\end{array}$ & $\begin{array}{l}\mathrm{EPC}= \\
(\mathrm{A}-\mathrm{B}) / \\
(\mathrm{E}-\mathrm{F})\end{array}$ & $\begin{array}{l}\text { EPC }>1 \text {, kebijakan bersifat protektif, semakin } \\
\text { besar nilai EPC berarti semakin tinggi } \\
\text { proteksi pemerintah terhadap komoditas } \\
\text { domestik. } \\
\text { EPC } \leq 1 \text {, kebijakan tidak bersifat protektif, } \\
\text { tidak ada proteksi pemerintah terhadap } \\
\text { komoditas domestik. }\end{array}$ \\
\hline b. Net Trasfer & $\mathrm{NT}=\mathrm{D}-\mathrm{H}$ & $\begin{array}{l}\text { NT }>0 \text {, menunjukkan tambahan surplus } \\
\text { produsen yang disebabkan oleh kebijakan } \\
\text { pemerintah yang diterapkan pada input dan } \\
\text { output. } \\
\text { NT } \leq 0 \text {, menunjukkan tidak ada tambahan } \\
\text { surplus produsen yang disebabkan oleh } \\
\text { kebijakan pemerintah yang diterapkan pada } \\
\text { input dan output. }\end{array}$ \\
\hline $\begin{array}{ll}\text { c. } & \text { Profitability } \\
\text { Coefficient }\end{array}$ & $\mathrm{PC}=\mathrm{D} / \mathrm{H}$ & $\begin{array}{l}\text { PC }>0 \text {, artinya secara keseluruhan kebijakan } \\
\text { pemerintah memberikan insentif kepada } \\
\text { produsen. } \\
\text { PC } \leq 0 \text {, artinya secara keseluruhan kebijakan } \\
\text { pemerintah tidak memberikan insetif kepada } \\
\text { produsen. }\end{array}$ \\
\hline $\begin{array}{l}\text { d. Subsidi Ratio to } \\
\text { Producer }\end{array}$ & $\mathrm{SRP}=\mathrm{L} / \mathrm{E}$ & $\begin{array}{l}\text { SRP }<0 \text {, artinya kebijakan pemerintah yang } \\
\text { berlaku selama ini menyebabkan produsen } \\
\text { mengeluarkan biaya produksi lebih besar } \\
\text { dari biaya imbangan untuk berproduksi. } \\
\text { SRP } \geq 0 \text {, artinya kebijakan pemerintah yang } \\
\text { berlaku selama ini tidak menyebabkan } \\
\text { produsen mengeluarkan biaya produksi } \\
\text { lebih besar dari imbangan untuk } \\
\text { berproduksi. }\end{array}$ \\
\hline
\end{tabular}




\section{HASIL DAN PEMBAHASAN}

\section{Biaya dan Penerimaan Usahatani}

Biaya-biaya dalam kegiatan usahatani kopi Robusta di Kabupaten Rejang Lebong terdiri dari biaya-biaya yang berasal dari input sarana produksi yang terdiri dari biaya penyambungan, pupuk, herbisida dan insektisida. Biaya tenaga kerja mulai dari kegiatan pengolahan lahan, penyambungan, pemupukan, penyemprotan, penyiangan, pemanenan, penjemuran, dan pengangkutan. Biaya lainnya yang juga dihitung adalah biaya alat-alat penunjang produksi, pajak, dan sewa lahan. Masing-masing-masing biaya kemudian dihitung berdasarkan harga privat, yaitu harga yang benar-benar diterima petani dan harga sosial yaitu harga yang seharusnya diterima petani jika pada kondisi pasar persaingan sempurna. Masing-masing komponen biaya tadi juga dikelompokkan ke dalam input produksi yang termasuk tradable dan non tradable.

Tabel 3. Biaya Produksi pada Usahatani Kopi Robusta di Kabupaten Rejang Lebong

\begin{tabular}{|c|c|c|c|c|c|}
\hline Jenis Input & $\begin{array}{c}\text { Vol/ } \\
\text { satuan }\end{array}$ & $\begin{array}{c}\text { Harga } \\
\text { Privat } \\
\text { (Rp/Unit) } \\
\end{array}$ & Biaya (Rp) & $\begin{array}{c}\text { Harga } \\
\text { Sosial } \\
\text { (Rp/Unit) }\end{array}$ & Biaya (Rp) \\
\hline $\begin{array}{l}\text { Penyambungan } \\
\text { (spin) }\end{array}$ & $2.581,51$ & $1.703,13$ & 4.396.647,13 & $1.703,13$ & 4.396.647,13 \\
\hline \multicolumn{6}{|l|}{ Pupuk (kg) } \\
\hline Urea & 130,16 & $1.882,77$ & $245.061,34$ & 5.600 & 728.896 \\
\hline Phoska & 256,41 & $2.718,23$ & $696.981,35$ & 5.500 & 1.410 .255 \\
\hline \multicolumn{6}{|l|}{ Herbisida(liter) } \\
\hline Gramoxon & 8,31 & 53.000 & 440.430 & 53.000 & 440.430 \\
\hline Noxson & 8,31 & 45.000 & 373.950 & 45.000 & 373.950 \\
\hline \multicolumn{6}{|l|}{ Insektisida (liter) } \\
\hline Drusban & 0,20 & 60.000 & 12.000 & 0,20 ltr & 12.000 \\
\hline $\begin{array}{l}\text { Tenaga } \quad \text { Kerja } \\
(\mathrm{HOK})\end{array}$ & 104,081 & 1.270 .000 & 3.565 .435 & 1.270 .000 & 3.565 .435 \\
\hline \multicolumn{6}{|l|}{ Biaya Alat (buah) } \\
\hline Cangkul & 1.87 & $41.615,39$ & 77.820 .78 & $41.615,39$ & 77.820 .78 \\
\hline Parang & 2,43 & 50.000 & 121.500 & 50.000 & 121.500 \\
\hline Sabit/Arit & 2,48 & $35.371,15$ & $87.720,452$ & $35.371,15$ & $87.720,452$ \\
\hline Alat semprot & 1,00 & 220.000 & 220 & 220.000 & 220 \\
\hline Terpal & 2,70 & $201.803,85$ & $544.870,395$ & $201.803,85$ & $544.870,395$ \\
\hline Gergaji & 2,84 & 25.000 & 58.500 & 25.000 & 58.500 \\
\hline Pajak & 1,04 ha & 9.900 & 10.296 & - & - \\
\hline Sewa lahan & 1,04 ha & 2.187 .500 & 2.275 .000 & 2.187 .500 & 2.275 .000 \\
\hline
\end{tabular}

Sumber: Data Primer diolah (2013)

6 | Fery Murtiningrum, Putri Suci Asriani, dan Redy Badrudin, Analisis Daya. 


\section{Analisis Keunggulan Kompetitif}

Pendekatan yang digunakan untuk mengukur daya saing suatu komoditas dapat dilihat dari keunggulan kompetitif dan komparatif. Salah satu alat analisis yang dapat digunakan untuk mengetahui daya saing suatu komoditi (keunggulan kompetitif dan keunggulan komperatif) adalah Matriks Analisis Kebijakan atau PAM (policy Analiysis Matriks) yang disusun berdasarkan data penerimaan, biaya produksi dan biaya lainnya yang dihitung berdasarkan harga finansial (privat) dan harga ekonomi (bayangan atau sosial). Masing-masing biaya produksi pada harga finansial dan ekonomi dibagi menjadi komponen tradable (asing) dan non tradable (domestik).

Tabel 4. Matriks Analisis Kebijakan Usahatani Kopi di Kabupaten Rejang Lebong Tahun 2013 (per Ha per Tahun)

\begin{tabular}{lrrrr}
\hline \multirow{2}{*}{ Uraian } & \multirow{2}{*}{ Penerimaan } & \multicolumn{2}{c}{ Biaya Input } & \multirow{2}{*}{ Keuntungan } \\
& & \multicolumn{1}{c}{ Tradable } & Non Tradable & \\
\hline Harga Privat & 32.218 .791 & $1.768 .422,70$ & $11.357 .789,75$ & $19.092 .577,55$ \\
Harga Sosial & 51.545 .920 & 2.965 .531 & $11.347 .493,75$ & $37.232 .895,63$ \\
Dampak Kebijakan & $(19.327 .129,38)$ & $(1.197 .107,30)$ & 10.296 & $(18.140 .318,08)$ \\
\hline
\end{tabular}

Sumber: Data primer (2013)

Penerimaan usahatani diperoleh dari hasil perkalian jumlah output yang dihasilkan dengan harga jual. Untuk penerimaan privat (privat provitability) harga jual didasarkan pada harga jual yang diterima oleh petani sebesar Rp. 12.903, sedangkan untuk analisis finansial menggunakan harga sosial berdasarkan harga fob (free on board) sebesar Rp 20.643. Jumlah produksi kopi rata-rata per hektar per tahun yang dihasilkan dari kegiatan usahatani kopi robusta di Kabupaten Rejang Lebong adalah sebesar $2.497 \mathrm{~kg}$, jumlah output ini dikalikan harga privat maka didapatkan penerimaan berdasarkan harga privat sebesar $\operatorname{Rp} 32.218 .791,00$.

Hasil analisis dengan metoda Policy Analysis Matrix (PAM) menunjukkan bahwa nilai PP untuk usahatani kopi di Kabupaten Rejang Lebong adalah Rp 19.092.578,55/ Ha/Tahun. Ini menunjukkan bahwa kegiatan usahatani kopi menguntungkan dan memiliki keuntungan kompetitif. Indikator efisiensi finansial dari pengusahaan suatu komoditi digambarkan oleh nilai PCR. Nilai PCR untuk usahatani kopi lebih kecil dari satu 1 yaitu sebesar 0,37 artinya usahatani kopi baik untuk diusahakan karena memiliki keunggulan kompetitif. Keunggulan kompetitif suatu komoditi dapat dilihat dari bagaimana alokasi sumberdaya diarahkan untuk mencapai efisiensi finansial dalam pengusahaan komoditi (Indriyati, 2007). Semakin rendah nilai PCR suatu komoditi maka akan semakin besar keunggulan kompetitif yang dimilikinya. 
Tabel 5. Hasil Analisis Keunggulan Kompetitif Matriks PAM

\begin{tabular}{cll}
\hline Uraian & Hasil & \multicolumn{1}{c}{ Kesimpulan } \\
\hline Private profitability (D) & $19.092 .578,55$ & $\begin{array}{l}\mathrm{D}>0, \text { Komoditas kopi robusta } \\
\text { mampu ekspansi karena memiliki } \\
\text { keuntungan yang diterima } \\
\text { langsung petani. }\end{array}$ \\
Private cost ratio (PCR) & PCR <1, komoditas yang diteliti \\
& 0,37 & memiliki keunggulan kompetitif. \\
\hline
\end{tabular}

Sumber: Data primer diolah (2013)

Nilai PCR 0,37 memiliki arti bahwa untuk mendapatkan tambahan output satu satuan pada harga privat diperlukan tambahan biaya faktor domestik atau non tradable sebesar 0,37 satuan atau untuk menghasilkan satu unit nilai tambah memerlukan biaya domestik yang lebih kecil dari satu unit yaitu sebesar 0,37, dengan kata lain bahwa Kabupaten Rejang Lebong memiliki kemampuan secara ekonomi dalam membiayai dan memproduksi kopi secara efisien dan secara finansial kopi yang dihasilkan dapat bersaing di pasar domestik dan internasional.

\section{Analisis Keunggulan Komperatif}

Keunggulan Komperatif suatu komoditas ditentukan oleh nilai-nilai keuntungan sosial (SP/ Social Profitability) dan nilai ratio sumber daya domestik (DRCR/Domestic Resource Cost Ratio).

Tabel 6 Hasil Analisis Keunggulan Komparatif Matriks PAM

\begin{tabular}{|c|c|c|}
\hline Uraian & Hasil & Kesimpulan \\
\hline Sosial Provitability (SP) & $39.232 .895,63$ & $\begin{array}{l}\mathrm{SP}>0 \text {, ada efisiensi } \text { dari sistem } \\
\text { komoditas pada kondisi tidak ada } \\
\text { divergensi }\end{array}$ \\
\hline Domestic Resource Cost & & kebijaksanaan efisien. \\
\hline Ratio (DRCR) & 0,23 & $\begin{array}{l}\text { Sistem komoditas } \\
\text { keunggulan komparatif. }\end{array}$ \\
\hline
\end{tabular}

Sumber: Data primer diolah (2013)

Hasil analisis dengan metode PAM menunjukkan bahwa nilai SP untuk usahatani kopi adalah Rp 39.232.895,63/Ha/Tahun. Ini menunjukkan bahwa usahatani kopi layak diusahakan dan memiliki keuntungan komparatif. Social Profitability (SP) adalah keuntungan yang diperoleh jika terjadi pasar persaingan sempurna, dimana tidak ada campur tangan pemerintah dan kegagalan pasar. Nilai DRCR usahatani kopi di Kabupaten Rejang Lebong berdasarkan hasil analisis adalah 0,23. Nilai tersebut menunjukkan bahwa

8 | Fery Murtiningrum, Putri Suci Asriani, dan Redy Badrudin, Analisis Daya. 
untuk mendapatkan 1 unit nilai tambah diperlukan biaya domestik sebesar 0,23 unit pada usahatani kopi.

\section{Dampak Kebijakan Pemerintah terhadap Input - Output}

Analisis kebijakan pemerintah pada input-output merupakan gabungan antara kebijakan input dan kebijakan output. Dampak kebijakan secara keseluruhan baik terhadap input maupun output dapat dilihat dari Koefisien Proteksi Efektif/ Efective protection Coefficient (EPC), Trasfer bersih/Net Trasfer (NT), Koefisien keuntungan/ Profitability Coefficient (PC) dan Rasio Subsidi bagi Produsen/Subsidi Ratio to Producer (SRP).

Tabel 7. Dampak Kebijakan Pemerintah terhadap Input - Output

\begin{tabular}{|c|c|c|}
\hline Uraian & Hasil & Kesimpulan \\
\hline $\begin{array}{l}\text { Efective } \\
\text { coefficient }\end{array}$ & 0,63 & $\begin{array}{l}\text { EPC } \leq 1 \text {, kebijakan tidak bersifat } \\
\text { protektif, tidak ada proteksi } \\
\text { pemerintah terhadap komoditas } \\
\text { domestik. }\end{array}$ \\
\hline Net Transfer & $(18.140 .317,08)$ & $\begin{array}{l}\text { NT } \leq 0 \text {, menunjukkan tidak ada } \\
\text { tambahan surplus produsen yang } \\
\text { disebabkan oleh kebijakan } \\
\text { pemerintah yang diterapkan pada } \\
\text { input dan output }\end{array}$ \\
\hline Profitability Coefficient & 0,512787905 & 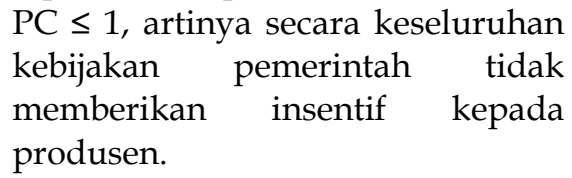 \\
\hline Subsidi ratio to Producer & $-0,351925377$ & $\begin{array}{l}\text { Kebijakan pemerintah yang berlaku } \\
\text { selama ini menyebabkan produsen } \\
\text { mengeluarkan biaya produksi lebih } \\
\text { besar dari biaya imbangan untuk } \\
\text { berproduksi. }\end{array}$ \\
\hline
\end{tabular}

Sumber: Data primer diolah (2013)

\section{Analisis Sensitivitas}

Penelitian ini menggunakan enam macam analisis sensitivitas dilakukan dengan dua cara yang berbeda. Lima analisis pertama adalah jika terjadi perubahan pada satu variabel saja dan variabel lain dianggap tetap (ceteris paribus), sedangkan analisis yang keenam adalah jika terjadi perubahan kelima variabel secara bersamaan. Ke lima analisis ini adalah pemerintah memberikan subsidi penyambungan Rp 1.000,00 per spin (tunas), harga herbisida naik $38,09 \%$, harga pupuk anorganik naik $35 \%$, jumlah output turun $56 \%$ dan harga output turun $57,35 \%$. 
Tabel 8. $\quad$ Analisis Sensitivitas

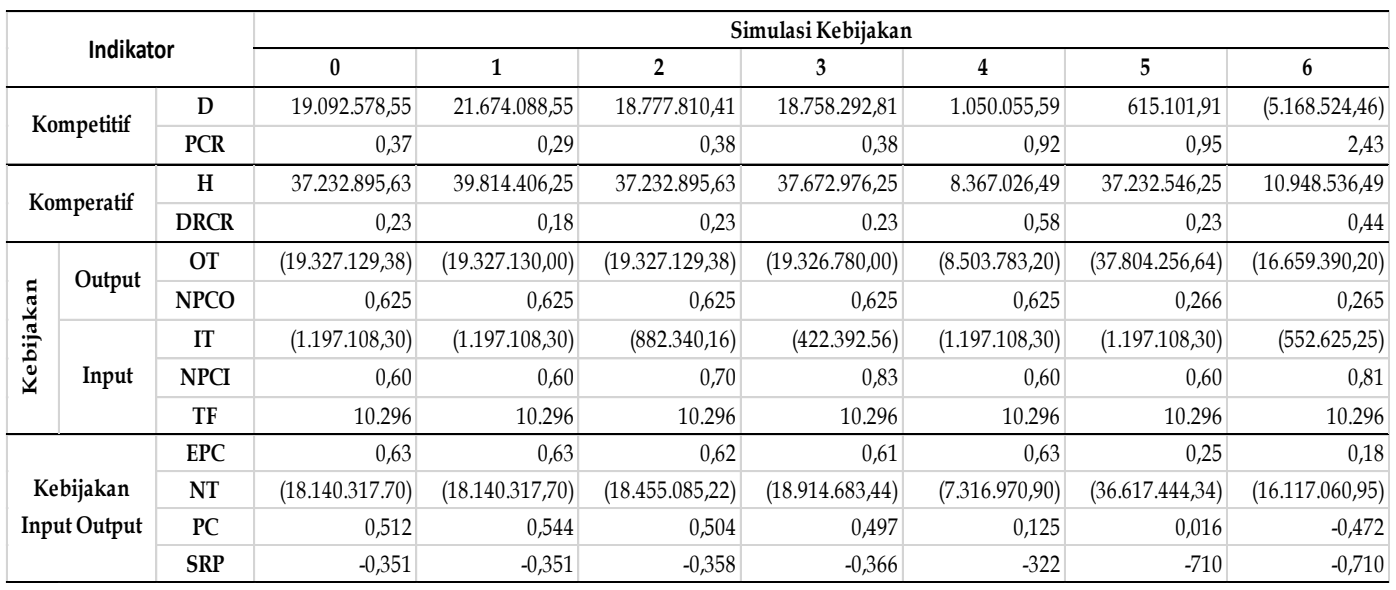

Sumber: Data primer diolah (2013)

$\begin{array}{lll}0 & =\text { Kondisi sekarang } \\ 1 & = & \text { Subsidi biaya penyambungan Rp. 1000/tunas } \\ 2 & = & \text { Input Herbisida meningkat 38,09 \% } \\ 3 & = & \text { Pupuk anorganik meningkat 35\% } \\ 4 & = & \text { Jumlah output menurun } 56 \% \\ 5 & =\text { Harga output menurun } 57,35 \% \\ 6 & =\text { Analisis gabungan }\end{array}$

\section{Dampak Subsidi Penyambungan}

Tabel 8 menunjukkan bahwa dengan adanya subsidi untuk biaya penyambungan dari pemerintah sebesar Rp 1.000,- per spin menyebabkan adanya kenaikan Keuntungan Sosial/Profit Provitability (PP) dari Rp 19.092.578,55 menjadi Rp 21.674.088,55. Keuntungan sosial/Social Provitability (SP) juga mengalami peningkatan dari $\mathrm{Rp} 37.232 .895,63$ menjadi sebesar Rp 39.814.406,25. Nilai PCR dan DRCR juga semakin kecil dan menurun di bawah 1 yaitu sebesar 0,29 untuk nilai PCR, dan 0,18 untuk nilai DRCR. Hal ini menunjukkan bahwa usahatani kopi robusta di Kabupaten Rejang Lebong semakin memiliki keunggulan kompetitif dan keunggulan komperatif.

Dampak Peningkatan Harga Input Herbisida dan Insektisida Sebesar 38,09\%

Herbisida merupakan salah satu input produksi yang penting pada usahatani kopi, karena banyak jenis pekerjaan yang membutuhkan herbisida seperti penyiangan rumput, dan penyemprotan serangga. Kenaikan harga input herbisida tidak menyebabkan nilai Keuntungan Privat dan Keuntungan Sosial pada pengusahaan komoditias kopi bernilai negatif, tetapi mengalami

10 | Fery Murtiningrum, Putri Suci Asriani, dan Redy Badrudin, Analisis Daya. 
penurunan untuk keuntungan privat dari $\mathrm{Rp}$ 19.092.578,55 menjadi $\mathrm{Rp}$ 18.777.810,41 dan untuk keuntungan sosial tetap pada kondisi $\mathrm{Rp}$ 37.232.895,63. Ini berarti walaupun terjadi kenaikan harga herbisida komoditas kopi tersebut masih layak untuk diusahakan baik secara finansial atau ekonomi.

\section{Dampak Kenaikan Harga Pupuk Anorganik 35\%}

Hasil analisis sensitivitas menunjukkan bahwa dengan kenaikan harga input pupuk anorganik sebesar 35 persen menyebabkan terjadinya penurunan nilai PP menjadi Rp 18.758.292,81/Ha/Tahun. Terjadinya penurunan penerimaan petani ini karena meningkatnya biaya produksi usahatani kopi robusta ini yang disebabkan meningkatnya biaya yang berasal dari sarana produksi dari Rp 1.882,77/Kg menjadi Rp 2.542/Kg untuk biaya pupuk urea, dan biaya pupuk phonska meningkat dari Rp 2.718,23/Kg menjadi Rp 3.669,61. Walaupun penerimaan petani menurun sebesar Rp 334.284,74 per hektar, ini tidak mempengaruhi nilai PCR dan DRCR, terlihat nilai PCR dan DRCR tidak mengalami perubahan. Kondisi ini sekali lagi membuktikan bahwa usahatani kopi robusta di Kabupaten Rejang Lebong mempunyai keunggulan kompetitif dan keunggulan komperatif. Hal ini dikarenakan potensi domestik sumber daya alam yang mendukung dengan kebutuhan tanaman kopi untuk tumbuh dan berkembang dengan baik, dan adanya penggunaan teknologi penyambungan serta didukung pemeliharaan yang baik dan intensif menyebabkan produktivitas kopi yang dihasilkan tinggi. Walaupun terjadi kenaikan harga pupuk anorganik mencapai 35 persen, usahatani kopi robusta di Kabupaten Rejang Lebong tetap mempunyai daya saing yang tinggi.

\section{Dampak Penurunan jumlah output sebesar 56\%}

Dari hasil analisis yang dilakukan didapatkan hasil bahwa jika terjadi penurunan jumlah output sebesar 56 persen, maka nilai keuntungan yang diterima petani menjadi semakin kecil yaitu sebesar Rp 1.050.055,59/Ha/Tahun. Nilai ini tidak mampu untuk menutupi biaya produksi petani baik dari input tradable sebesar $\mathrm{Rp} 1.768 .423,70$, dan tentu saja biaya input non tradable sebesar Rp 11.357.789,75 (pada kondisi harga privat yang diterima oleh petani). Bahkan jika pun petani mendapatkan harga sosial sesuai fob yang berlaku ternyata belum mampu untuk menutupi biaya produksi yang telah dikeluarkan oleh petani yang berasal dari biaya input tradable sebesar Rp 2.965.531,- dan biaya input non tradable sebesar Rp 11.347.493,75. Penurunan jumlah output sebesar 56 persen ini juga mengakibatkan nilai PCR dan DRCR naik menjadi 0,92 dan 0,58. Walaupun tetap berada dibawah 1 (satu), yang artinya tetap mempunyai daya saing secara kompetitif dan komperatif, tetapi dengan meningkatnya nilai PCR dan DRCR ini menunjukkan bahwa daya saing usahatani kopi Robusta di 
Kabupaten Rejang Lebong mengalami penurunan secara kompetitif dan komperatif.

Penurunan daya saing yang terjadi karena penurunan jumlah output sebesar 56 persen ini menujukkan bahwa daya saing dipengaruhi oleh faktor agroekologi (Soetriono, 2009) yaitu dari faktor internal usahatani itu sendiri yaitu jumlah output yang dihasilkan. Daya saing mengalami penurunan ketika jumlah output yang dihasilkan menurun. Walaupun nilai PCR dan DRCR usahatani kopi robusta di Kabupaten Rejang Lebong mengalami penurunan, tetap saja memiliki keunggulan kompetitif dan keunggulan komperatif, yang artinya mempunyai kelayakan dan kemampuan untuk bersaing dengan komoditas sejenis dari tempat lain. Kasus penurunan jumlah output ini dapat dihindari dengan penggunaan teknologi yang ada dan pemeliharan yang intensif, dan kalaupun terjadi bisa karena faktor eksternal yang tidak bisa dikendalikan oleh manusia seperti bencana alam dan serangan hama dari wilayah lain.

\section{Dampak Penurunan Harga Output Sebesar 57,35\%}

Penurunan harga output pada tingkat harga tertinggi yang pernah dialami petani bedasarkan analisis ternyata sangat berpengaruh terhadap keuntungan yang diterima oleh petani. Petani hanya menerima keuntungan sebesar Rp 615.101,91/Ha/Tahun. Kondisi ini menyebabkan petani belum mampu untuk menutupi ongkos produksi baik dari biaya input tradable sebesar Rp 1.768.422,70 dan input non tradable sebesar Rp 11.357.789,75. Nilai PCR mengalami peningkatan dari 0,37 menjadi 0,95. Sementara nilai DRCR tetap pada kondisi 0,23 . Nilai PCR yang mendekati satu menunjukkan bahwa usahatani kopi robusta di Kabupaten Rejang Lebong mengalami penurunan daya saing secara kompetitif karena menurunnya harga output. Penurunan harga output ini menunjukkan bahwa persoalan daya saing bukan saja disebabkan faktor internal dari kegiatan usahatani itu sendiri tapi juga dipengaruhi oleh faktor eksternal (Soetriono, 2009). Dalam hal ini kondisi perekonomian pasar kopi internasional karena seperti diketahui bahwa harga kopi dunia ditentukan dari pasar perekonomian internasional melalui wadah International Organization Coffea (ICO).

\section{Dampak gabungan (per Ha per tahun)}

Dari hasil analisis yang dilakukan, didapatkan hasil jika terjadi kenaikan harga input herbisida, insektisida, dan pupuk anorganik, juga terjadi penurunan jumlah output yang dihasilkan dan diikuti penurunan nilai jual output (walaupun pemerintah memberikan subsidi untuk biaya penyambungan kepada petani pada saat perekonomian mengalami 5 peubah tadi), maka petani sama sekali tidak menerima manfaat apapun dari kegiatan usahataninya. Hal ini ditunjukkan dengan terjadi kerugian sebesar Rp 
5.168.524,46, walaupun untuk harga sosial petani mendapatkan keuntungan sebesar Rp 10.948.536,49. Kerugian ini terutama disebabkan selisih harga jual yang cukup jauh antara harga privat yang diterima oleh petani dengan harga jual di tingkat fob (free on board)-nya.

\section{SIMPULAN DAN SARAN}

\section{Simpulan}

Berdasarkan hasil penelitian yang telah di lakukan maka dapat disimpulkan:

1. Usahatani kopi Robusta di Kabupaten Rejang Lebong mempunyai keunggulan kompetitif yang tinggi dan mempunyai keunggulan komperatif.

2. Adanya kebijakan pemerintah terhadap input sarana produksi tradable berupa subsidi sangat memberikan manfaat kepada petani untuk meningkatkan penerimaan mereka.

3. Berdasarkan analisis sensitivitas maka usahatani kopi robusta di Kabupaten Rejang Lebong masih tetap mempunyai daya saing yang tinggi walaupun mengalami perubahan kondisi input-output baik secara kompetitif dan komperatif. Jika terjadi perubahan input-output secara serentak karena perubahan kondisi perekonomian maka usahatani kopi robusta di Kabupaten Rejang Lebong tetap memiliki keunggulan komperatif tetapi tidak memiliki keunggulan keunggulan kompetitif.

\section{Saran}

Adapun saran peneliti dari hasil penelitiannya:

1. Perlu adanya kebijakan input-output agar dapat melindungi petani kopi sehingga petani dapat menerima harga privat yang bagus untuk meningkatkan penerimaan mereka.

2. Subsidi terhadap input tradable tetap dipertahankan agar usahatani kopi tetap mempunyai daya saing kompetitif yang baik.

3. Perlu dilakukan penelitian lebih lanjut untuk melihat sejauh mana dampak penerapan teknologi penyambungan terhadap keunggulan usahatani kopi robusta di Kabupaten Rejang Lebong. 
ISSN: $1412-8837$

\section{DAFTAR PUSTAKA}

BPS Bengkulu. 2011. Rejang Lebong dalam Angka. Laporan Tahunan Hutbun.

Indriyati, Sari. 2007. Analisis Daya Saing Buah Nenas Model Tumpang Sari Dengan Karet (Kasus di Desa Sungai Medang, Kecamatan Cambai, Prabumulih dan di Desa Payaraman, Kecamatan Tanjung Batu, Ogan Ilir, Provinsi Sumatera Selatan). IPB. Bogor.

Monke, E.A., and E.S. Pearson. 1989. The Policy Analysis Matrix for Agricultural Development. Cornel University Press. London.

Panggabean. 2011. Buku Pintar Kopi. Jakarta.

Soetriono. 2009. Strategi Peningkatan Daya Saing Agribisnis Kopi Robusta dengan Model Daya Saing Tree Five. Pusat Analisis Sosial Ekonomi dan Kebijakan Pertanian; Badan Penelitian dan Pengembangan Pertanian. Departemen Pertanian. Jakarta.

14 | Fery Murtiningrum, Putri Suci Asriani, dan Redy Badrudin, Analisis Daya. 